\title{
STATYSTYCZNO-PORÓWNAWCZA ANALIZA XXIII MIĘDZYNARODOWEGO KONGRESU BIZANTYNOLOGICZNEGO (BELGRAD, 22-27 VIII 2016)
}

Dokładnie w pięć lat po XXII Międzynarodowym Kongresie Bizantynologicznym w Sofii ${ }^{1}$ odbyło się w Belgradzie kolejne, XXIII już spotkanie badaczy historii Bizancjum o zasięgu światowym. Choć oficjalne rozpoczęcie obrad miało miejsce faktycznie w poniedziałek, 22 sierpnia, to jednak rejestracja uczestników rozpoczęła się już w niedzielę, 21 września, w godzinach od 12:00 do 20:00, w gmachu Rektoratu Uniwersytetu Belgradzkiego (Studentski Trg 1, 11000 Belgrad)2. Ostatnim dniem kongresu była sobota, 27 sierpnia. W poniedziałek, 22 sierpnia, o godzinie 10:00, w auli Wydziału Filologicznego (Studentski Trg 3) miała miejsce oficjalna inauguracja kongresu. Jako pierwszy głos zabrał Tomislav Nikolić (ur. 15 II 1952), prezydent Republiki Serbii. Następnie krótkie wprowadzenie wygłosili prof. Johannes Koder (ur. 6 VII 1942), przewodniczący Association Internationale des Études Byzantines (AIEB), i prof. Ljubomir Maksimović (ur. 27 XI 1938), przewodniczący Serbskiego Narodowego Komitetu Studiów Bizantynologicznych. Na zakończenie uroczystej sesji otwarcia kongresu wykład inauguracyjny wygłosił prof. John F. Haldon (Uniwersytet Princeton): ,Change” in Byzantium. Thinking about Stability, Resilence and Movement in Medieval East Roman Society.

1. Kongres w liczbach. Po otwierających belgradzkie spotkanie fajerwerkach i fleszach przyszedł czas na rutynowa, kongresową ,szarzyznę". Według oficjalnych danych zawartych $\mathrm{w}$ List of participants ${ }^{3}$, którą - jak podano na ostatniej stronie tego wykazu - zamknięto 26 lipca, w XXIII

* Dr hab. Piotr Kochanek, prof. KUL - kierownik Katedry Historii Starożytnej i Bizantyńskiej w Instytucie Historii na Wydziale Nauk Humanistycznych Katolickiego Uniwersytetu Lubelskiego Jana Pawła II; e-mail: lu2005harn@yahoo.de.

${ }^{1}$ Por. P. Kochanek, XXII Międzynarodowy Kongres Bizantynistów (Sofia, 22-27 VIII 2011), VoxP 31 (2011) t. 56, 942-951.

${ }^{2}$ Możliwość rejestracji istniała zresztą przez cały czas trwania kongresu: poniedziałek (8:0020:00), wtorek-piątek (8:30-20:00) i sobota (8:30-14:00).

${ }^{3}$ List of participants of the 23 ${ }^{\text {rd }}$ International Congress of Byzantine Studies (Belgrade, 22-27 August 2016), Belgrade 2016. Wykaz ten nie posiada numeracji stron. 
Międzynarodowym Kongresie Bizantynologicznych wzięło udział 1258 osób z 48 krajów świata. Z drugiej strony w teczce z materiałami kongresowymi, którą otrzymał każdy zarejestrowany uczestnik belgradzkiego spotkanie, znajdowała się jednostronicowa lista uzupełniająca, na której figuruje 12 nowych nazwisk ${ }^{4}$, co zwiększyło liczbę uczestników do 1270 . Jednakże do tejże teczki dołączono jeszcze jedna, tym razem trzystronicową erratę, która korygowała program kongresu ${ }^{5}$. Wynika z niej, że 10 innych osób odwołało swój udział, a zatem ostateczna liczba oficjalnych uczestników to 1260 osób.

Z kolei w programie kongresu widnieje 1187 nazwisk $^{6}$. Nie oznacza to jednak, że w Belgradzie wystapiło właśnie tylu prelegentów. Analiza tego programu pozwala bowiem stwierdzić, że 28 osób nie wygłosiło żadnego referatu. Osoby te bądź przewodniczyły różnego typu sesjom, bądź też, jak np. prof. J. Koder i prof. L. Maksimović, wygłaszały tylko krótkie przemówienia okolicznościowe w czasie sesji otwierającej i zamykającej belgradzki kongres. Ponadto 10-ciu prelegentów odwołało oficjalnie swój udział w kongresie, zaś jedna osoba odwołała swoje wystapienie. W konsekwencji do liczby 28 należy dodać 11, co daje w sumie 39 personas mutas. Rzeczywista zatem liczby prelegentów to 1148 osób. Ponieważ zaś, jak wyżej wspomniano, w kongresie wzięło udział w sumie 1260 badaczy, zatem 112 osób (=8,888\%) potraktowało wyprawę do Serbii jako wojaż turystyczno-krajoznawczy, co przy tak dużej liczbie zarejestrowanych uczestników nie jest procentem wysokim.

Osoby te miały swe wystapienia w ramach sześciu typów sesji: 1) sesja inauguracyjna (1); 2) sesje plenarne (6); 3) sesje okragłostołowe (49); 4) wolne komunikaty (116); 5) sesje specjalne (6 w 9-ciu odsłonach); 6) prezentacje posterów (2). W ramach sesji inauguracyjnej, jak już wyżej wspomniano, tylko prof. J.F. Haldon (Uniwersytet Princeton) wygłosił około półgodzinny referat. Z kolei na sześciu sesjach plenarnych, z których pierwsza i ostatnia (poniedziałkowa i sobotnia) odbywały się w auli Wydziału Filologicznego, natomiast cztery pozostałe (wtorek-piątek) miały miejsce w gmachu Serbskiej Akademii Nauk i Umiejętności (Knez Mihailova 35, 11001 Belgrad), przedstawiono 20 komunikatów, z których każdy miał trwać według założeń gospodarzy 15 minut (w sesji sobotniej tylko 10 minut) ${ }^{7}$, jednak prelegenci regularnie przekraczali ów limit, starając się nadać swym wystąpieniom charakter poważnych referatów na miarę rangi przedmiotowego kongresu. Należy zaznaczyć, że wszystkie wystąpienia

${ }^{4}$ List of participants of the $23^{\text {rd }}$ International Congress of Byzantine Studies. Additions and corrections, Belgrade 2016.

${ }^{5}$ Program of the $23^{\text {rd }}$ International Congress of Byzantine Studies. Additions and corrections, Belgrade 2016.

${ }^{6}$ Program of the 23 $3^{\text {rd }}$ International Congress of Byzantine Studies (Belgrad, 22-27 August 2016), Belgrade 2016. Należy dodać, że pierwszych 14 stron programu nie posiada paginacji, stąd w przypisach niniejszego artykułu sprawozdawczego są one numerowane jako [s. I-XIV].

${ }^{7}$ Tamże, [s. IX]. 
z sesji plenarnych zostały wcześniej opublikowane w formie pracy zbiorowej ${ }^{8}$, którą otrzymał każdy oficjalnie zarejestrowany uczestnik kongresu. Warto dodać, że aula Serskiej Akademii Nauk i Umiejętności mogła pomieścić zaledwie 170 osób. Jednak ta niewielka liczba miejsc okazała się zupełnie wystarczająca, ponieważ na sali było zwykle obecnych 70 do 90 ,kongresmenów”. Powodem tak niskiej frekwencji, prócz wielu czysto indywidualnych przyczyn, mógł być wspomniany wyżej fakt wcześniejszego opublikowania tych wystąpień, co umożliwiało każdemu zainteresowanemu zapoznanie się z nimi w dogodnym dla siebie czasie. Większość wystąpień kongresowych była jednak zgrupowana w dwóch zasadniczych blokach: A) sesje okragłostołowe; B) wolne komunikaty. Łącznie odbyło się, jak już wyżej zaznaczono, 49 sesji okragłostołowych, w czasie których wygłoszono 382 prelekcje. Każda z nich miała trwać około 10 minut ${ }^{9}$. Najwięcej, bo aż 116 sesji objęły wolne komunikaty, w czasie których przedstawiono 843 mini-referaty. Długość tych wystapień przewidziano na 10 do 15 minut $^{10}$. Niemal wszystkie powyższe sesje odbyły się w salach Wydziału Filologicznego. Tylko cztery sesje okragłostołowe miały miejsce w sali $\mathrm{nr} 2$ gmachu Serbskiej Akademii Nauk i Umiejętności ${ }^{11}$. Liczbę uczestników zarówno sesji okragłostołowych, jak i tzw. wolnych komunikatów określono w przedziale od 6 do 10 osób $^{12}$. Streszczeń tych 1225 wystapień nie opublikowano jednak w formie osobnych tomów, co było dobrą praktyką wcześniejszych kongresów bizantynologicznych, lecz zamieszczono je tylko na stronie internetowej kongresu ${ }^{13}$. Piątym segmentem wystapień kongresowych były sesje specjalne. Sesji tych było oficjalnie 6, lecz sesja piąta została podzielona na cztery części, co w sumie dało 9 spotkań sesyjnych. Łącznie objęły one 64 prezentacje, przedstawiane zarówno przez indywidualnych badaczy, jak i przez grupy skupione wokół danego projektu, ponieważ w ramach tych sesji omawiano: instrumenta studiorum (sesja 1.2.4) ${ }^{14}$, kwestie związane z digitalizacją zarówno w obrębie humanistyki jako takiej, jak i bizantynologii (sesja 3: The Digital Humanities and Byzantine Studies ${ }^{15}$, aktualne i przyszłe projekty badawcze z tego zakresu (sesja 5/1-4: Present and Future Projects: Presentation of Research Centers and Their Projects in the Field of Byzantine Studies) ${ }^{16}$ oraz - jak to określono - Futur of the Byzantine Studies (sesja 6) ${ }^{17}$. Wszystkie sesje specjalne odbywały się

\footnotetext{
${ }^{8}$ Proceedings of the $23^{r d}$ International Congress of Byzantine Studies. Plenary Papers, ed. S. Marjonović-Dušanić, Belgrade 2016.

${ }^{9}$ Por. nota 7.

${ }^{10}$ Program of the $23^{\text {rd }}$ International Congress of Byzantine Studies, [s. X].

${ }^{11}$ Tamże, s. 22, 50-51, 65-66 i 72-73.

${ }^{12}$ Por. nota 7,9 i 10.

${ }^{13}$ Streszczenia te znajdują się w odpowiednich zakładkach na stronie: www.byz2016.rs/program [dostęp: 19.09.2016].

${ }^{14}$ Program of the $23^{\text {rd }}$ International Congress of Byzantine Studies, s. 17-18, 32-33 i 54-55.

15 Tamże, s. 40.

${ }^{16}$ Tamże, s. 70, 77-78, 85 i 86.

${ }^{17}$ Tamże, s. 109-110.
} 
w auli Serbskiej Akademii Nauk i Umiejętności. Prezentacja jednego projektu miała trwać około 10 minut, a liczba prelegentów określona została na 8 do 10 osób $^{18}$. Sesje te nie posiadają streszczeń na stronie internetowej kongresu, mimo deklaracji organizatorów ${ }^{19}$. Wreszcie szóstym typem wystapień kongresowych były prezentacje posterów. W programie znalazły się dwa tego typu spotkania, na których przedstawiono 19 posterów ${ }^{20}$. Prezentacje te odbywały się w holu głównym Wydziału Filologicznego, a czas tych wystąień nie był oficjalnie limitowany. W sumie wspomnianych wyżej 1148 badaczy przedstawiło 1329 prelekcji: $1=$ sesja inauguracyjna $(=0,075 \%) ; 20=$ sesje plenarne $(=1,504 \%) ; 382$ $=$ sesje okragłostołowe $(=28,743 \%) ; 843=$ wolne komunikaty $(=63,431 \%) ; 64$ $=$ sesje specjalne $(=4,815 \%) ; 19=$ prezentacje posterów $(=1,429 \%)$.

Różnica pomiędzy liczbą prelegentów a liczbą prelekcji bierze się stąd, że niektórzy badacze zgłosili kilka komunikatów. Rekordzistą w tym względzie został prof. Christian Gastgeber (ur. 20 II 1970) z Austriackiej Akademii Nauk w Wiedniu, który miał aż 6 indywidualnych wystapieńn ${ }^{21}(6 / 1329$ $=0,451 \%)$. Z kolei sześć osób zgłosiło po cztery indywidualne prelekcje ${ }^{22}$ $(24 / 1329=1,805 \%)$, a 26 osób zabierało głos indywidualnie 3 razy $^{23}(78 / 1329$ $=5,869 \%$ ). Było też 114 bizantynologów, którzy zgłosili po dwa indywidualne komunikaty $(228 / 1329=17,155 \%)$. Zatem $w$ sumie owych 147 prelegentów (na $1148=12,804 \%$ ) miało łącznie 336 wystapień (na $1329=25,282 \%$ ), będąc swego rodzaju kołem zamachowym belgradzkiego kongresu.

$\mathrm{Z}$ drugiej strony zdarzały się występy grupowe: i tak w Belgradzie wystąpiło 46 duetów, 5 tercetów ${ }^{24}, 4$ kwartety $^{25}, 1$ kwintet $^{26}$ oraz 2 sekstety ${ }^{27}$. Jeśli dodać do tego fakt, o którym już wyżej była mowa, że każde wystąpienie kongresowe miało trwać od 10 do 15 minut, to w tej sytuacji można jeszcze zrozumieć prelekcje wygłaszane w duecie, ale wszystkie inne komunikaty zbiorowe

${ }^{18}$ Tamże, [s. X].

${ }^{19}$ Tamże.

${ }^{20}$ Tamże, s. 94-95 i 102-103. Pierwotnie zaplanowano, że w ramach każdej prezentacji zostanie przedstawionych 10 posterów, jednak w ostatniej chwili Mikhail Denisov wycofał swoje wystapienie, por. Program of the $23^{\text {rd }}$ International Congress of Byzantine Studies. Additions and corrections, [s. 3].

${ }^{21}$ Program of the 23rd International Congress of Byzantine Studies, s. 22, 32, 40, 50, 72 i 109.

${ }^{22}$ Byli to: J.F. Haldon, Flora Karagianni, Sergei Mariev, Ekaterini Mitsiou, Mihailo St. Popović i Johannes Preiser-Kapeller.

${ }^{23}$ Byli to: Eirini Artemi, Alessandra Bucossi, Jean-Claude Cheynet, Salvatore Cosentino, Olivier Delouis, Vincent Déroche, Andrii Domanovskyi, Alexandra Evdokimova, Bernard Flusin, Mikhail V. Fomin, László Horváth, Frederick Lauritzen, Kirill A. Maksimovič, Dominic Moreau, Dan J. Mureşan, Philip Niewöhner, Brendan Osswald, Eleftheria Papagiannis, Symeon Paschalidis, Claudia Rapp, Alessandra Ricci, Filippo Ronconi, Juan Signes Codoñer, Myrto Veikou, Athanasios K. Vionis, Staffan Wahlgren.

${ }^{24}$ Program of the $23^{\text {rd }}$ International Congress of Byzantine Studies, s. 15, 78, 85 i 86 (2x).

${ }^{25}$ Tamże, s. 15, 66, 88 i 101.

${ }^{26}$ Tamże, s. 85.

${ }^{27}$ Tamże, s. 85. Por. Program of the $23^{\text {rd }}$ International Congress of Byzantine Studies. Additions and corrections, [s. 2-3]. 
jawią się raczej li tylko jako zabieg, który pozwolił kilku osobom zaistnieć na liście kongresowych prelegentów i wzbogacić ich naukowy życiorys.

Wystapienia kongresowe były wygłaszane w 6 językach: po angielsku $(1057$ prelekcji na $1329=79,533 \%)$, francusku $(165 / 1329=12,415 \%)$, grec$\mathrm{ku}(30 / 1329=2,257 \%)$, niemiecku $(28 / 1329=2,106 \%)$, rosyjsku $(28 / 1329$ $=2,106 \%)$ i włosku $(21 / 1329=1,580 \%)$. Trzeba jednak zaznaczyć, że powyższe dane, zaczerpnięte z programu kongresu i dołączonej do niego erraty, nie oddają stanu faktycznego. Niektórzy bowiem badacze, choć tytuł swego wystapienia podali w programie np. po francusku, to w czasie obrad wygłaszali swą prelekcję po angielsku ${ }^{28}$, czego świadkiem był niżej podpisany. Oficjalny program kongresu nie oddaje zatem obrazu powszechności użycia języka angielskiego. W porównaniu do poprzedniego kongresu, który odbył się w roku 2011 w Sofii, użycie języka angielskiego uległo rozszerzeniu. W Sofii bowiem, gdzie w sumie wygłoszono 935 wykładów, 699 (oficjalnie), czyli 74,759\%, było $\mathrm{w}$ języku angielskim ${ }^{29}$, gdy tymczasem w Belgradzie ten oficjalny procent wzrósł do 79,533\%. Ekspansji języka angielskiego realny „opór” stawiał tylko język francuski. Natomiast Niemcy niemal całkowicie skapitulowali, przechodząc na dużo bardziej komunikatywny angielski, co można uznać także za stanowisko zdroworozsądkowe, mające zwiększyć zasięg i skuteczność oddziaływania nauki niemieckiej na badaczy anglojęzycznych z całego świata.

Warto również przyjrzeć się uczestnikom kongresu biorąc za punkt wyjścia afiliacje, jakie widnieją przy poszczególnych nazwiskach na List of participants of the 23rd International Congress of Byzantine Studies. Należy przy tym zaznaczyć, że bardzo wielu „kongresmanów”, bo aż 157, nie podało żadnej afiliacji, w czym prym wiedli, jak wynika z poniższej tabeli, Grecy (48), Włosi (20) i Serbowie (16). W tej grupie byli zarówno emerytowani pracownicy naukowi, jak i doktoranci oraz tzw. badacze niezależni. Pewną liczbę osób bez afiliacji należy też tłumaczyć opieszałością samych zainteresowanych $\mathrm{w}$ wypełnianiu formularza wpisowego. $Z$ drugiej strony należy pamiętać, że afiliacja nie ma często nic wspólnego $z$ obywatelstwem danego kraju, a jest tylko dowodem na atrakcyjność konkretnych ośrodków studiów bizantynologicznych w świecie. Stąd wielu badaczy podaje nie swój kraj pochodzenia, czy miejsce pracy, lecz znany ośrodek w którym w danym momencie przebywa.

${ }^{28}$ Przykładem może być komunikat wygłoszony na sesji plenarnej w środę, 24 sierpnia, przez prof. Béatrice Caseau (Uniwersytet Paris-Sorbonne = Paris IV). Oficjalny tytuł (Rituels chrétiens et sensorialité, w: Program of the $23^{\text {rd }}$ International Congress of Byzantine Studies, s. 41) wskazywał jednoznacznie, że prelegentka będzie mówić po francusku, tym bardziej że w tym języku został wydrukowany: B. Caseau, Rituels chrétiens et sensorialité, w: Proceedings of the $23^{\text {rd }}$ International Congress of Byzantine Studies, s. 159-173. Tymczasem wykład odbył się po angielsku. Podobnie było w przypadku komunikatu prof. Nafsiki Panselinou (Ateńska Wyższa Szkoła Sztuk Pięknych), której temat komunikatu brzmiał: Influences de l'art occidental sur la représentation de l'Annonciation dans des icônes post-byzantines $d u X V^{e}$ au XIXe siècle, w: Program of the $23^{r d}$ International Congress of Byzantine Studies, s. 89. Autorka mówiła jednak po angielsku.

${ }^{29}$ Por. Kochanek, XXII Międzynarodowy Kongres Bizantynistów, s. 946. 
W przypadku doktorantów, którzy nie posiadają często konkretnej afiliacji „krajowej”, jest to swego rodzaju „rewia marek”, która pokazuje ich aspiracje i możliwości. Statystyczne ujęcia kwestii afiliacji uczestników kongresu stara się przedstawić poniższa tabela. Wynika z niej, że na kongresie były według oficjalnych danych reprezentowane 373 instytucje naukowo-badawcze z 48 krajów świata. Wśród tych instytucji ogromną większość stanowiły uniwersytety. Pewne przemyślenia i refleksje może nasunąć Czytelnikowi analiza samej poniższej tabeli, stąd zbędne wydaje się tutaj jej szczegółowe omawianie.

\begin{tabular}{|c|c|c|c|c|c|c|}
\hline Lp. & Kraj & $\begin{array}{c}\text { Liczba } \\
\text { instytucji } \\
\text { afiliujących }\end{array}$ & $\begin{array}{l}\text { Uczestnicy } \\
\text { kongresu } \\
\mathrm{z} \text { afiliacją }\end{array}$ & $\begin{array}{c}\text { Uczestnicy } \\
\text { kongresu } \\
\text { bez afiliacji }\end{array}$ & $\begin{array}{c}\text { Ogólna } \\
\text { liczba } \\
\text { uczestników }\end{array}$ & $\begin{array}{c}\text { Procentowy } \\
\text { udział } \\
\text { w kongresie }\end{array}$ \\
\hline 1. & Albania & 6 & 10 & 2 & 12 & $0,952 \%$ \\
\hline 2. & Argentyna & 2 & 2 & - & 2 & $0,158 \%$ \\
\hline 3. & Armenia & 3 & 6 & - & 6 & $0,476 \%$ \\
\hline 4. & Australia & 10 & 14 & 2 & 16 & $1,269 \%$ \\
\hline 5. & Austria & 2 & 36 & 3 & 39 & $3,095 \%$ \\
\hline 6. & Belgia & 3 & 19 & 3 & 22 & $1,746 \%$ \\
\hline 7. & Białoruś & 1 & 1 & 1 & 2 & $0,158 \%$ \\
\hline 8. & Bułgaria & 15 & 55 & 2 & 57 & $4,523 \%$ \\
\hline 9. & Chiny & 1 & 2 & - & 2 & $0,158 \%$ \\
\hline 10. & Chorwacja & 1 & 1 & - & 1 & $0,079 \%$ \\
\hline 11. & Cypr & 5 & 16 & 1 & 17 & $1,349 \%$ \\
\hline 12. & Czarnogóra & 1 & 1 & - & 1 & $0.079 \%$ \\
\hline 13. & Czechy & 4 & 4 & - & 4 & $0,317 \%$ \\
\hline 14. & Dania & 2 & 6 & 1 & 7 & $0,555 \%$ \\
\hline 15. & Finlandia & 3 & 5 & 1 & 6 & $0,476 \%$ \\
\hline 16. & Francja & 25 & 94 & 9 & 103 & $8,174 \%$ \\
\hline 17. & Grecja & 31 & 164 & 48 & 212 & $16,825 \%$ \\
\hline 18. & Gruzja & 8 & 15 & 3 & 18 & $1,428 \%$ \\
\hline 19. & Hiszpania & 7 & 10 & 2 & 12 & $0,952 \%$ \\
\hline 20. & Holandia & 4 & 9 & 1 & 10 & $0,793 \%$ \\
\hline 21. & Irlandia & 1 & 1 & - & 1 & $0,079 \%$ \\
\hline 22. & Izrael & 6 & 13 & 2 & 15 & $1,190 \%$ \\
\hline 23. & Japonia & 3 & 4 & - & 4 & $0,317 \%$ \\
\hline 24. & Kanada & 4 & 4 & 1 & 5 & $0,396 \%$ \\
\hline 25. & Liban & 1 & 1 & - & 1 & $0,079 \%$ \\
\hline 26. & Łotwa & - & - & 1 & 1 & $0,079 \%$ \\
\hline 27. & Macedonia & 5 & 14 & 3 & 17 & $1,349 \%$ \\
\hline 28. & Mołdawia & 1 & 1 & - & 1 & $0,079 \%$ \\
\hline 29. & Niemcy & 23 & 67 & 5 & 72 & $5,714 \%$ \\
\hline 30. & Norwegia & 2 & 6 & - & 6 & $0,476 \%$ \\
\hline 31. & Polska & 11 & 25 & 1 & 26 & $2,063 \%$ \\
\hline 32. & Portugalia & 2 & 2 & - & 2 & $0,158 \%$ \\
\hline 33. & Rosja & 19 & 75 & 12 & 87 & $6,904 \%$ \\
\hline 34. & Rumunia & 12 & 26 & 1 & 27 & $2,142 \%$ \\
\hline 35. & San Marino & 1 & 1 & - & 1 & $0,079 \%$ \\
\hline 36. & Serbia & 14 & 106 & 16 & 122 & $9,682 \%$ \\
\hline 37. & Singapur & 1 & 1 & - & 1 & $0,079 \%$ \\
\hline 38. & Słowacja & 2 & 2 & - & 2 & $0,158 \%$ \\
\hline 39. & Słowenia & 1 & 1 & - & 1 & $0,079 \%$ \\
\hline 40. & Szwajcaria & 7 & 16 & 2 & 18 & $1,428 \%$ \\
\hline 41. & Szwecja & 1 & 6 & - & 6 & $0,476 \%$ \\
\hline 42. & Turcja & 19 & 40 & - & 40 & $3,174 \%$ \\
\hline
\end{tabular}




\begin{tabular}{|c|l|c|c|c|c|c|}
\hline 43. & Ukraina & 4 & 6 & 2 & 8 & $0,634 \%$ \\
\hline 44. & USA & 46 & 61 & 3 & 64 & $5,079 \%$ \\
\hline 45. & Watykan & 4 & 5 & - & 5 & $0,396 \%$ \\
\hline 46. & Wegry & 5 & 20 & 1 & 21 & $1,666 \%$ \\
\hline 47. & W. Brytania & 20 & 71 & 8 & 79 & $6,269 \%$ \\
\hline 48. & Włochy & 24 & 58 & 20 & 78 & $6,190 \%$ \\
\hline \multicolumn{2}{|c|}{ Suma } & $\mathbf{3 7 3}$ & $\mathbf{1 1 0 3}$ & $\mathbf{1 5 7}$ & $\mathbf{1 2 6 0}$ & $\mathbf{1 0 0 \%}$ \\
\hline
\end{tabular}

Tabela 1: Wykaz instytucji afiliujących i uczestników XXIII Kongresu Bizantynologicznego według afiliacji.

Tematyka wystapień kongresowych obejmowała tzw. całość problematyki związanej z bardzo szeroko rozumianą kulturą bizantyńską, jej oddziaływaniem oraz recepcją. Poziom wystapień był bardzo różny. Z drugiej strony warto zwrócić uwagę, na wyakcentowaną już wyżej długość prelekcji kongresowych. Gospodarze na wszystkie wystapienia, nawet na referaty wygłaszane w czasie sesji plenarnych, przewidzieli od 10 do 15 minut. Z technicznego punktu widzenia ograniczenie to było konieczne, aby w ciagu sześciu dni można było dopuścić do głosu 1148 mówców z 1329 referatami. Z drugiej strony ,taśmociąg prelekcyjny" to raj dla konferencyjnych turystów, ponieważ pozwala występować z zupełnie banalnymi, podręcznikowymi tekstami, których celem jest zwykle tylko chęć zaliczenia dużego, międzynarodowego meetingu naukowego. Przy tej skali przedsięwzięcia jest to zresztą klasyczny efekt tła. Nie on jednak decyduje o obliczu kongresów, które stanowią dobra, czasem wręcz jedyną okazję do spotkania twarzą w twarz eminentnych badaczy, wyznaczających kierunki rozwoju danej dyscypliny. Dużą wartość miały także sesje specjalne, szczególnie te, na których prezentowano instrumenta studiorum (sesja 1.2.4)

2. Udział Polaków w kongresie belgradzkim. Polskę reprezentowała w Belgradzie ekipa złożona z 26 osób (=2,063\% wszystkich uczestników kongresu; $=2,264 \%$ wszystkich prelegentów kongresu), które przybyły do stolicy Serbii z prelekcjami. W sumie przedstawili oni 29 krótkich referatów $(=2,182 \%$ wszystkich prelekcji kongresowych): $3 \mathrm{w}$ ramach sesji okragłostołowych, $24 \mathrm{w}$ ramach wolnych komunikatów i $2 \mathrm{w}$ czasie sesji specjalnych.

W kategorii sesji okragłostołowych swe komunikaty przedstawili: 1) dr Adam Izdebski (Uniwersytet Jagielloński): Vegetation Patterns and Anthropogenic Landscapes in Byzantium ${ }^{31}$; 2) prof. dr hab. Maciej Kokoszko (Uniwersytet Łódzki): The Chickpea (દُpéßıvOos; Cicer arietinum L.) as Food and Medicine in Early Byzantine Medical Writings ${ }^{32}$; 3) dr Nikolaos Zagklas (Uniwersytet Śląski): The Circulation of Theodore Prodromos' Poetry in the Twelfth Century and beyond: Between Poetic Circles and Anthologies ${ }^{33}$.

\footnotetext{
${ }^{30}$ Por. nota 14.

${ }^{31}$ Program of the 23 ${ }^{\text {rd }}$ International Congress of Byzantine Studies, s. 48.

32 Tamże, s. 49.

33 Tamże, s. 23.
} 
Z kolei w ramach wolnych komunikatów głos zabierały następujące osoby: 1) dr Marcin Böhm (Uniwersytet Opolski): The Konstostephanos Family - Worst or the Best Mega Dukes of Kommenian Navy in the 12 $2^{\text {th }}$ Century; Some Remarks on the History of the Navy of the Empire of Nicaea in the Light of the Chronicle of Georgios Akropolites. Wygłosił on dwie prelekcje w czasie jednej sesji wolnych komunikatów, która miała za temat: The Byzantine Sea ${ }^{34}$; 2) dr hab. Sławomir Bralewski, prof. UŁ: Loi ecclésiastique selon Socrate de Constantinople ${ }^{35}$; 3 ) dr Zofia Brzozowska (Uniwersytet Łódzki): The Image of Maria Lekapene, Peter and the Byzantine-Bulgarian Relations between 927 and 969 A.D. in the Light of Old Russian Sources ${ }^{36}$; 4) dr Paweł Filipczak (Uniwersytet Łódzki): The Byzantine Administration in Syro-Palestine on the Eve of the Arab Invasion. Selected Problems ${ }^{37}$; 5) dr Piotr Łukasz Grotowski (Papieski Uniwersytet Jana Pawła II w Krakowie): A Shepherd's Crook and a Stone Cut Out without Hands: The Changing Character of Attributes in the Iconography of Byzantine Saints ${ }^{38}$; 6) dr hab. Piotr Kochanek, prof. KUL: Vignetten von Konstantinopel auf mittelalterlichen und frühneuzeitlichen Weltkarten $^{39}$; 7) dr Andrzej Kompa (Uniwersytet Lódzki): Higher Education in Constantinople - A University or Not?; The Constantinopolitan Authors, the Constantinopolitan Point of View? - Groups and Individuals as Seen by the Authors Active in the Early Byzantine Capital. Miał on dwa wystapienia w czasie dwóch różnych sesji $\left.{ }^{40} ; 8\right)$ dr Bogna Kosmulska (Uniwersytet Warszawski): Was There a Place for Parrhesia in the $7^{\text {th }}$ Century Byzantium? ${ }^{41}$; 9) dr hab. Mirosław Piotr Kruk, prof. UG: The Corpus of Icons from the $14^{\text {th }}-16^{\text {th }}$ Century in the Collection of the National Museum in Krakow ${ }^{42}$; 10) mgr Tomasz Labuk (Uniwersytet Śląski): Niketas Choniates and the ", Silence of History”: Historical Discourse on the Fringe ${ }^{43}$; 11) prof. dr hab. Mirosław Jerzy Leszka (Uniwersytet Łódzki): Спорные вопросы правления болгарского изаря Пempa I (927-969). Było to wspólne wystąpienie z dr Kiriłem Marinowem4; 12) dr Magdalena Łaptaś (Uniwersytet Kardynała Stefana Wyszyńskiego w Warszawie): Byzantine or Non-Byzantine Rituals of the Nubian Rulers ${ }^{45}$;

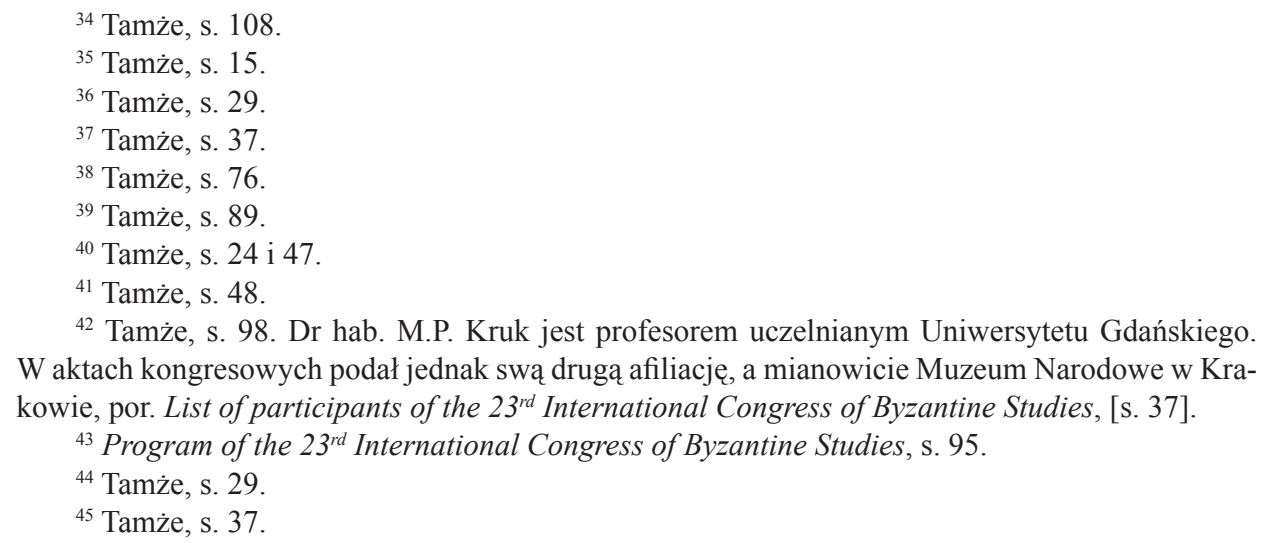

${ }^{42}$ Tamże, s. 98. Dr hab. M.P. Kruk jest profesorem uczelnianym Uniwersytetu Gdańskiego. W aktach kongresowych podał jednak swą drugą afiliację, a mianowicie Muzeum Narodowe w Krakowie, por. List of participants of the 23 $3^{\text {rd }}$ International Congress of Byzantine Studies, [s. 37].

${ }^{43}$ Program of the $23^{\text {rd }}$ International Congress of Byzantine Studies, s. 95.

${ }^{44}$ Tamże, s. 29.

${ }^{45}$ Tamże, s. 37. 
13) dr hab. Przemysław Marciniak, prof. UŚ: Hypokrisis and Mimesis - Byzantine Concepts of Theatrical and Non-Theatrical Imitation ${ }^{46}$; 14) dr Kirił Marinow (Uniwersytet Łódzki): Geopolitics of the First Bulgarian State, Seventh-Eleventh Centuries; Cпорные вопросы правления болгарского ияаря Пempa I (927-969). Drugi komunikat prelegent wygłosił w duecie z prof. M.J. Leszką. Oba wystąpienia miały miejsce w czasie w jednej sesji wolnych komunikatów, której temat brzmiał: The First Bulgarian Empire ${ }^{47}$. 15) dr Michał Pawlak (badacz niezależny, uformowany w środowisku bizantynologów Uniwersytetu Łódzkiego ${ }^{48}$ ): Infertility and Statesmanship: The Case of John VIII Palaiologos (1392-1448)49; 16) mgr Michał Pietranik (Uniwersytet Warszawski): Relics Captured during the War and Their Role in Byzantium during the Macedonian Dynasty ${ }^{50}$; 17) mgr Łukasz Pigoński (Uniwersytet Łódzki): Marcian, the Soldier-Emperor, and the Early Byzantine Military Elites ${ }^{51}$; 18) dr Adrian Szopa (Uniwersytet Pedagogiczny im. KEN w Krakowie): The Barbarians in Service of the Late Roman Empire in the East ${ }^{52}$; 19) dr Katarzyna Warcaba (Uniwersytet Ślaski): A Transtextual Analysis of the „Katomyomachia" 53 ; 20) dr hab. Teresa Wolińska, prof. UŁ: The Use of the Title of Basileus in Procopius' Writings and Basileia of Arethas ${ }^{54}$; 21) mgr Jan Wolski (Uniwersytet Łódzki): Tsar Peter, Monastic Tsardom and Byzantinisation. A Historiographical Survey ${ }^{55}$; 22) dr hab. Marcin Wołoszyn, prof. URz: Making Border of Kievan Rus' Visible. Finds of Kolts from Poland ${ }^{56}$.

Wreszcie podczas sesji specjalnych przedstawiono dwa komunikaty: 1) dr Dorota Dzierzbicka (Uniwersytet Warszawski): The Egyptian Bazaar. A Stu$d y$ of Trade Networks in Egypt from the $1^{\text {st }}$ Century BC to the $7^{\text {th }}$ Century $\left.A D^{57} ; 2\right)$ dr Nikolaos Zagklas (Uniwersytet Śląski): Editing Byzantine Poetry: Neglected Works, Overlooked Editorial Aspects and Future Challenges ${ }^{58}$.

${ }^{46}$ Tamże, s. 81 .

${ }^{47}$ Tamże, s. 29.

${ }^{48}$ Michał Pawlak uzyskał stopień doktora nauk humanistycznych w dyscyplinie historia (specjalność: bizantynistyka) 2 września 2015. Promotorem jego rozprawy były dr hab. Małgorzata Dąbrowska, prof. UŁ - Wydział Filozoficzno-Historyczny Uniwersytetu Łódzkiego (Katedra Historii Średniowiecznej).

${ }^{49}$ Program of the $23^{\text {rd }}$ International Congress of Byzantine Studies, s. 77.

${ }^{50}$ Tamże, s. 61.

${ }^{51}$ Tamże, s. 24.

${ }^{52}$ Tamże, s. 47.

${ }^{53}$ Tamże, s. 84.

${ }^{54}$ Tamże, s. 15.

${ }^{55}$ Tamże, s. 29.

${ }^{56}$ Tamże, s. 82. Dr hab. M. Wołoszyn jest profesorem uczelnianym Uniwersytetu Rzeszowskiego. W aktach kongresowych podał jednak swą drugą afiliację, a mianowicie PAN (Instytut Archeologii i Etnologii) w Warszawie, por. List of participants of the $23^{\text {rd }}$ International Congress of Byzantine Studies, [s. 78].

${ }^{57}$ Program of the $23^{\text {rd }}$ International Congress of Byzantine Studies, s. 78.

${ }^{58}$ Tamże, s. 33. 
Badacze reprezentujący Polskę posługiwali się głównie językiem angielskim. W nim zostało wygłoszonych 26 komunikatów $(=89,655 \%)$. Następnie jeden komunikat przedstawiono po francusku $(3,448 \%)$, jeden po niemiecku $(=3,448 \%)$ i jeden po rosyjsku $(=3,448 \%)^{59}$.

Tytułem uzupełnienia powyższych danych należy dodać, że po dwa komunikaty przedstawili: dr M. Böhm (Uniwersytet Opolski); dr A. Kompa (Uniwersytet Łódzki) i dr N. Zagklas (Uniwersytet Śląski). Natomiast dr K. Marinow (Uniwersytet Łódzki) miał 11/2 wystapienia, ponieważ jedno z nich głosił wspólnie z prof. dr hab. M.J. Leszką (Uniwersytet Łódzki). Ponadto sześć osób z tego grona współprzewodniczyło różnego typu sesjom. I tak jednej sesji okragłostołowej (Food, Environment and Landscape in Byzantium), która odbyła się w środę (24 sierpnia), współprzewodniczył wraz z prof. Jamesem Crow (Uniwersytet w Edynburgu) dr A. Izdebski (Uniwersytet Jagielloński) ${ }^{60}$. Z kolei pięć sesji wolnych komunikatów współmoderowali: 1) dr hab. S. Bralewski, prof. UŁ i prof. Roger Scott (Uniwersytet Melbourne) w poniedziałek (22 sierpnia): Historiography $4^{\text {th }}-9^{\text {th }}$ Centuries $\left.^{61} ; 2\right)$ dr P.Ł. Grotowski (Papieski Uniwersytet Jana Pawła II w Krakowie) i dr Mirjana Gligorijević Maksimović (Uniwersytet w Belgradzie) w piątek (26 sierpnia): Studies in Byzantine Iconography - Part $2^{62}$; 3) dr K. Marinow (Uniwersytet Łódzki) i prof. Vassil Gjuzelev (Bułgarska Akademia Nauk) we wtorek (23 sierpnia): The First Bulgarian Empire ${ }^{63}$; 4) dr hab. M. Wołoszyn, prof. URz oraz prof. Aleksandr Musin (Rosyjska Akademia Nauk w Petersburgu) i dr Perica Spehar (Uniwersytet

${ }^{59}$ Por. nota 68-69 i 73 oraz tabela 2. Z danych zamieszczonych w tych odnośnikach wynika, że w sumie Polacy wygłosili w Belgradzie 30 komunikatów, należy bowiem doliczyć mgra J. Sypiańskiego, który reprezentował uniwersytet w Moguncji i wygłosił swój komunikat po francusku. Daje to następujące proporcje: 26 wystąpień na 30 po angielsku $(=86,666 \%), 2 / 30$ po francusku $(=6,666 \%), 1 / 30$ po niemiecku $(=3,333 \%), 1 / 30$ po rosyjsku $(=3,333 \%)$. Ponieważ zaś wszystkich referatów kongresowych przedstawiono 1329 , zatem wkład polski wynosił 2,257\%. Jeśli chodzi o języki, jakimi posługiwała się „reprezentacja Polski” na wcześniejszych kongresach bizantynologicznych, to kwestia ta przedstawia się następująco: 1) Na pięciu pierwszych kongresach (19241936), które odbyły się w okresie międzywojennym, Polacy wygłosili łącznie 17 referatów: 11 po niemiecku, 5 po francusku i 1 po włosku, por. P. Kochanek, Udział Polaków w 21 Międzynarodowych Kongresach Bizantynistów w latach 1924-2006, VoxP 32 (2012) t. 57, 330; M. Kozłowski, Kazimierz Zakrzewski na tle dyskusji o upadku cesarstwa rzymskiego w polskiej historiografii okresu międzywojennego, w: Kazimierz Zakrzewski. Historia i polityka, red. M. Dąbrowska, Warszawa - Łódź 2015, 47 i nota 5; 2) Na szesnastu kongresach powojennych (VI-XXI: 1948-2006) Polacy mieli najprawdopodobniej 41 wystąpień: 20(?) po angielsku, 17 po francusku, 2 po niemiecku i 2 po rosyjsku, por. Kochanek, Udziat Polaków w 21 Międzynarodowych Kongresach Bizantynistów, s. 332 i nota 130. Statystyka ta ukazuje ogromny spadek użycia języka niemieckiego po II wojnie światowej, który uważano powszechnie za język agresora, a następnie dewaluację języka francuskiego wraz z upadkiem polityczno-kulturalnej pozycji Francji jako takiej.

${ }^{60}$ Program of the $23^{\text {rd }}$ International Congress of Byzantine Studies, s. 48.

${ }^{61}$ Tamże, s. 15.

${ }^{62}$ Tamże, s. 93.

${ }^{63}$ Tamże, s. 29. 
w Belgradzie) w czwartek (25 sierpnia): Fashion in Transition: From Byzantium to the Byzantine Commonwealth ${ }^{64}$; 5) dr N. Zagklas (Uniwersytet Śląski) i prof. Elizabeth Jeffreys (Uniwersytet w Oxfordzie) w czwartek (25 sierpnia): Literature in the Age of the Komnenoi ${ }^{65}$.

Wymienieni wyżej badacze reprezentowali 11 polskich uniwersytetów. Najwięcej osób, bo aż 11 reprezentowało środowisko bizantynologów łódzkich: dr hab. S. Bralewski, prof. UŁ, dr Z. Brzozowska, dr P. Filipczak, prof. dr hab. M. Kokoszko, dr A. Kompa, prof. dr hab. M.J. Leszka, dr K. Marinow, dr M. Pawlak, mgr Ł. Pigoński, dr hab. T. Wolińska, prof. UŁ, mgr J. Wolski. Wygłosili oni w sumie 12 komunikatów. W ten sposób historycy Bizancjum z Łodzi zdeklasowali inne polskie środowiska, zajmujące się tym segmentem historii powszechnej. Znakomicie zadebiutował też Uniwersytet Sląski, którego ekipa liczyła 4 osoby: mgr T. Labuk, dr hab. P. Marcinak, prof. UŚ, dr K. Warcaba, dr N. Zagklas. Wygłosiły one 5 prelekcji. Na trzeciej pozycji znalazł się Uniwersytet Warszawski, który reprezentowało w Belgradzie trzech badaczy: dr D. Dzierzbicka, dr. B. Kosmulska, mgr M. Pietranik. Pozostałe polskie ośrodki studiów bizantynologicznych obecne na kongresie były reprezentowane przez pojedyncze osoby: Katolicki Uniwersytet Lubelski Jana Pawła II - dr hab. P. Kochanek, prof. KUL; Papieski Uniwersytet Jana Pawła II w Krakowie - dr P.Ł. Grotowski; Uniwersytet Gdański - dr hab. M.P. Kruk, prof. $\mathrm{UG}^{66}$; Uniwersytet Jagielloński - dr A. Izdebski; Uniwersytet Kardynała Stefana Wyszyńskiego w Warszawie - dr M. Laptaś; Uniwersytet Opolski dr M. Böhm (wygłosił on dwa komunikaty); Uniwersytet Pedagogiczny im. KEN w Krakowie - dr A. Szopa; Uniwersytet Rzeszowski - dr hab. M. Wołoszyn, prof. URz ${ }^{67}$. Jeśli chodzi o stopnie i tytuły naukowe to w ekipie polskiej było 2 profesorów tytularnych, 6 doktorów habilitowanych, 14 doktorów i 4 magistrów (doktorantów). Wielkim nieobecnym na belgradzkim kongresie był Uniwersytet im. Adama Mickiewicza w Poznaniu.

W kongresie wzięła również udział dwójka Polaków, którzy byli afiliowani do ośrodków zagranicznych. Byli to: mgr Jakub Sypiański (Johannes Gutenberg Universität - Moguncja) ${ }^{68}$ oraz mgr Agnieszka Szymańska (Temple University - Filadelfia). Pierwsza z wymienionych osób wygłosiła komunikat (Une mention de l'ambassade ,assyrienne” de Photius dans un manuscript arabe?) $\mathrm{w}$ ramach jednej z sesji okragłostołowych ${ }^{69}$. Natomiast Pani A. Szymańska

\footnotetext{
${ }^{64}$ Tamże, s. 82.

65 Tamże, s. 83.

${ }^{66}$ Por. nota 42.

${ }^{67}$ Por. nota 57.

${ }^{68}$ Mgr J. Sypiański jest absolwentem UW, a w Moguncji przebywał do września 2016 w charakterze stypendysty Deutscher Akademischer Austauschdienst (DAAD). Por. nota 59 i 73.

${ }^{69}$ Program of the 23 ${ }^{\text {rd }}$ International Congress of Byzantine Studies, s. 22.
} 
figuruje tylko na liście uczestników kongresu ${ }^{70}$, lecz w jego programie nazwisko jej nie pojawia się, ponieważ nie miała w Belgradzie żadnego wystąpienia. Ponadto, według rozeznania niżej podpisanego, przynajmniej dwie osoby z Polski wzięły udział w belgradzkim spotkaniu, lecz ich nazwiska nie figurują ani na oficjalnej liście uczestników kongresu, ani też w wykazie prelegentów. Byli to: mgr Agnieszka Piórecka (doktorantka UW) i mgr Roman Szlązak (doktorant UKSW). Jest możliwe, że również inni Polacy nieoficjalnie wzięli udział w kongresie, lecz ich nazwiska nie są znane piszącemu ten artykuł sprawozdawczy, choćby dlatego, że zebranie takich danych jest trudne i zwykle bywa ono dziełem przypadku.

Wobec 1260 oficjalnie zarejestrowanych uczestników kongresu liczba 26 reprezentantów Polski (+ 2 Polaków z zagranicy), czyli 2,063\% (lub 2,222\%) ogółu „kongresmenów”, nie jest imponująca i nie oddaje potencjału polskiego środowiska bizantynologicznego. W XXII Kongresie w Sofii (22-27 VIII 2011) wzięło bowiem udział 34 badaczy krajowych i 4 z zagranicy, co stanowiło 3,074\% (lub 3,435\%) ogółu uczestników ${ }^{71}$. Z drugiej strony kongres belgradzki zgromadził drugą co do liczebności ekipę polską w całej historii tych międzynarodowych spotkań badaczy historii Bizancjum ${ }^{72}$. Systematycznie zagadnienie to przedstawia poniższa tabela:

\begin{tabular}{|l|c|c|c|c|c|}
\hline \multicolumn{7}{|c|}{ Sofia 2011} \\
\hline stopień naukowy & mgr & $\mathrm{dr}$ & $\mathrm{dr}$ hab. & $\begin{array}{c}\text { profesor } \\
\text { tytularny }\end{array}$ & suma \\
\hline liczba osób & 9 & 16 & 9 & 4 & 38 \\
\hline procent & $23,684 \%$ & $42,105 \%$ & $23,684 \%$ & $10,526 \%$ & $100 \%$ \\
\hline liczba referatów & 7 & 16 & 8 & 4 & 35 \\
\hline procent & $20,000 \%$ & $45 \%, 714$ & $22,857 \%$ & $11,428 \%$ & $100 \%$ \\
\hline \multicolumn{7}{|c|}{ Belgrad $\mathbf{2 0 1 6}$} & \multicolumn{1}{|c|}{} \\
\hline stopień naukowy & $\mathrm{mgr}$ & $\mathrm{dr}$ & $\mathrm{dr}$ hab. & $\begin{array}{c}\text { profesor } \\
\text { tytularny }\end{array}$ & suma \\
\hline liczba osób & 6 & 14 & 6 & 2 & 28 \\
\hline procent & $21,428 \%$ & $50,000 \%$ & $21,428 \%$ & $7,142 \%$ & $100 \%$ \\
\hline liczba referatów & 5 & 17,5 & 6 & 1,5 & 30 \\
\hline procent & $16,666 \%$ & $58,333 \%$ & $20,000 \%$ & $5,000 \%$ & $100 \%$ \\
\hline
\end{tabular}

Tabela 2: Udział poszczególnych kategorii polskich pracowników naukowych (również tych z afiliacją zagraniczną) w dwóch ostatnich kongresach ${ }^{73}$.

${ }^{70}$ List of participants of the $23^{\text {rd }}$ International Congress of Byzantine Studies, [s. 68].

${ }^{71}$ Por. Kochanek, XXII Międzynarodowy Kongres Bizantynistów, s. 950.

${ }^{72}$ Por. Kochanek, Udział Polaków w 21 Międzynarodowych Kongresach Bizantynistów, s. 309335. Zob. też Kozłowski, Kazimierz Zakrzewski na tle dyskusji o upadku cesarstwa rzymskiego, s. 47 i nota 5.

${ }^{73}$ W Sofii było 34 oficjalnie zarejestrowanych bizantynologów z Polski. Do tej liczby (34) 
Przyczyn spadku liczby uczestników należy doszukiwać się zarówno w nieciekawej sytuacji finansowej pracowników naukowych, jak i pewnym zmęczeniu środowiska permanentnymi, nieudolnymi reformami nauki i szkolnictwa wyższego w naszym kraju. Pogłębia to poczucie bezsensu tzw. pracy naukowej oraz marnowania życia, szczególnie ludzi młodych, na wykonywanie czynności świadomie i przypuszczalnie złośliwie marginalizowanych przez tzw. polityków. Mimo to aktualny poziom uczestnictwa polskich bizantynologów w ostatnich dwóch kongresach jest nie do porównania z okresem wcześniejszym, a szczególnie $\mathrm{z}$ okresem realnego socjalizmu ${ }^{74}$. Jednak dla uchwycenia istoty zachodzących obecnie zjawisk potrzeba analizy statystyczno-merytorycznej następnych kongresów. Dopiero tak ujęty problem może stanowić podstawę do głębszych analiz i do wyciągania dalej idących wniosków. Nie ulega jednak wątpliwości, że badania nad historią Bizancjum cieszą się w Polsce sporym zainteresowaniem, w czym jest niekwestionowana wielka zasługa poprzedniego pokolenia badaczy, którzy mimo trudności tworzyli podstawy współczesnej polskiej bizantynologii ${ }^{75}$. Warto o tym pamiętać, aby nie przypisywać sobie zasług innych. Poza tym historyk powinien znać i pamiętać o dziejach własnej dyscypliny, choćby dla dobra historii historiografii i dystansu do własnego ego. $\mathrm{Z}$ powyższej tabeli wynika również, że w ostatnich latach tzw. kongresowymi wołami roboczymi polskiej bizantynologii są osoby ze stopniem naukowym doktora, które w aktualnej sytuacji awansowej są niemal zmuszane do wypruwania sobie żył w drodze do uzyskania habilitacji.

3. Epilog. Jak informuje rozesłany drogą mailową Komunikat 6/2016: Sekcja Bizantynologiczna KNoKA PAN. Komisja Bizantynologiczny PTH ${ }^{6}$ w czasie obrad kongresu, w piątek 26 sierpnia 2016, między godziną 11:00 a 19:00, „odbyło się w gmachu serbskiej Kinoteki Zgromadzenie Generalne AIEB, w którym uczestniczyły wszystkie komitety narodowe stowarzyszenia,

należy dodać 4 Polaków, którzy byli oficjalnie afiliowani do ośrodków zagranicznych, por. Kochanek, XXII Międzynarodowy Kongres Bizantynistów, s. 947-948 i 948, nota 36. Jeśli zaś chodzi o wystapienia kongresowe, to $4 \mathrm{z}$ wyżej wymienionych osób przybyły do Sofii bez referatu, 2 osoby miały po dwa wystapienia, a dwóch innych badaczy zaprezentowało wspólnie jeden komunikat, por. tamże, s. 950. Natomiast na kongresie belgradzkim do 29 komunikatów bizantynologów afiliowanych do ośrodków polskich należy dodać komunikat wygłoszony przez mgra J. Sypiańskiego, który był afiliowany do Johannes Gutenberg Universität w Moguncji. W ten sposób w Belgradzie Polacy wygłosili 30 prelekcji. Por. nota 59 i 68.

${ }^{74}$ Por. Kochanek, Udziat Polaków w 21 Międzynarodowych Kongresach Bizantynistów, s. 330-332.

${ }^{75}$ Por. J. Naumowicz - M. Salamon, Profesor Oktawiusz Jurewicz (30 IV 1926 - 28 IV 2016), VoxP 66 (2016) t. 66, 715-719.

${ }^{76}$ K. Ilski - M. Kokoszko - A. Kompa, Komunikat 6/2016: Sekcja Bizantynologiczna KNoKA PAN. Komisja Bizantynologiczny PTH, Łódź, 5 września 2016. Autorem tego komunikatu, jak to zaznaczono na ostatniej z dwóch jego stron, jest de facto dr A. Kompa (UŁ). 
w liczbie 36 (38)"'77. Polskę reprezentowali na tym zgromadzeniu prof. dr hab. M. Kokoszko (UŁ), przewodniczący Polskiego Komitetu Narodowego AIEB, i dr A. Kompa (UŁ), sekretarz tegoż komitetu ${ }^{78}$. W miejsce odchodzącego składu Biura Międzynarodowego AIEB, którego 5-letnia kadencja (2011-2016) dobiegła końca ${ }^{79}$, wybrano nowy na okres 2016-2021: prof. J.F. Haldon (Uniwersytet Princeton) - przewodniczący; prof. Juan Signes Codoñer (Uniwersytet w Valladolid) - wiceprzewodniczacy; prof. Béatrice Caseau (Uniwersytet Paris-Sorbonne $=$ Paris IV $)-$ skarbnik; Vincent Déroche $($ Centre National de la Recherche Scientifique, Paryż) - zastępca skarbnika; prof. Athanasios Markopoulos (Uniwersytet Narodowy im. Kapodistriasa w Atenach) - sekretarz; Taxiarchis Kolias (Uniwersytet Narodowy im. Kapodistriasa w Atenach) - zastępca sekretarza. Warto w tym miejscu przypomnieć, że w strukturach centralnych AIEB zasiada dwóch Polaków: dr hab. M. Wołoszyn, prof. URz, jest członkiem Komisji Rozwoju AIEB, natomiast dr K. Marinow (UŁ) został członkiem nowo utworzonej Komisji Geografii Historycznej i Badań Przestrzennych. Zgromadzenie Generalne wybrało również miejsce XXIV kongresu, którym został Stambuł. W przywołanym wyżej Komunikacie 6/2016 przedstawiono szczegóły głosowania, do którego ,zgłoszono trzy kandydatury: Stambuł (referowała prof. Nevra Necipoğlu), Monachium (referował prof. Albrecht Berger), Nikozję (referował prof. Charalampos G. Chotzakoglou). W pierwszym głosowaniu tajnym otrzymały głosów (każdemu komitetowi narodowemu przysługiwał jeden głos): Stambuł - 15, Nikozja - 12, Monachium - 11. W drugim głosowaniu otrzymały głosów: Stambuł - 24, Nikozja - 14. [...] Delegacja polska złożyła głosy w pierwszym głosowaniu na rzecz kandydatury Monachium, w drugim - Stambułu. W wolnych wnioskach przewodnicząca komitetu austriackiego, prof. Claudia Rapp, zgłosiła kandydaturę Wiednia jako miejsca Kongresu w roku 2026" 80 .

Kongresowi towarzyszyły: 8 wystaw, koncert muzyki prawosławnej, pokazy filmów dokumentalnych na temat klasztorów i poszczególnych regionów

77 Tamże, [s. 1]. Liczba 36 (38) wynika stąd, że w czasie obrad Zgromadzenia Generalnego AIEB przyjęto do tej organizacji, obok już istniejących 36 komitetów narodowych AIEB, dwa nowe: argentyński i macedoński. Na czele komitetu argentyńskiego stoi prof. Pablo Adrián Cavallero (Academia Argentina de Letras / Uniwersytet Buenos Aires). Natomiast komitetowi macedońskiemu przewodniczy prof. Toni Filiposki (Uniwersytet św. Cyryla i Metodego w Skopje).

${ }^{78}$ Wiceprzewodniczącym Polskiego Komitetu Narodowego AIEB jest aktualnie prof. dr hab. Kazimierz Ilski (UAM).

${ }^{79}$ Oto skład ustępującego zarządu: przewodniczący - prof. J. Koder (Austriacka Akademia Nauk); wiceprzewodniczaccy - prof. J.F. Haldon (Uniwersytet Princeton); sekretarz - prof. Athanasios Markopoulos (Uniwersytet Narodowy im. Kapodistriasa w Atenach); zastępca sekretarza - prof. Sophia Kalopissi-Verti (Uniwersytet Narodowy im. Kapodistriasa w Atenach); skarbnik - prof. Michel Kaplan (Uniwersytet Paris 1 Panthéon-Sorbonne); zastępca skarbnika - prof. Arietta Papaconstantinou (Uniwersytet w Reading), por. Kochanek, XXII Międzynarodowy Kongres Bizantynistów, s. 951. Wiele ważnych informacji można znaleźć na stronie AIEB: www.aiebnet.gr/en/ lub www.aiebnet.gr/fr/.

${ }^{80}$ Ilski - Kokoszko - Kompa, Komunikat 6/2016, [s. 2]. 
Serbii w średniowieczu oraz 7 wycieczek autokarowych. W skład imprez towarzyszących wchodziły również targi książki. Polska była tutaj reprezentowana przez publikacje bizantynologiczne Wydawnictwa Uniwersytetu Łódzkiego. Serbowie wydali też dwa przyjęcia na cześć uczestników kongresu. Pierwsze z nich odbyło się już w niedzielę, 21 sierpnia, wieczorem (18:30). Jego gospodarzem był prezydent Serbii, Tomislav Nikolić, który podjął „,kongresmenów" w Pałacu Prezydenckim. Drugie przyjęcie odbyło się w ratuszu miejskim, w piątek (26 sierpnia) o godzinie 20:30, a jego gospodarzem był burmistrz Belgradu Siniša Mali ${ }^{81}$.

XXIII Międzynarodowy Kongres Bizantynologiczny przeszedł do historii. Należy docenić ogromny wysiłek serbskich gospodarzy włożony w sprawny i bezpieczny jego przebieg. Warto przypomnieć, że stolica Serbii była po raz drugi miejscem światowego spotkania bizantynologów, ponieważ tutaj miał miejsce również II Kongres (11-16 czerwca 1927), w którym wzięło udział 200 osób, reprezentujących 16 krajów ${ }^{82}$. Warto także dodać, że kongres belgradzki jest prawdopodobnie drugim co do liczby uczestników (1260) spotkaniem badaczy Bizancjum na przestrzeni całej historii tych zjazdów, a nie można wykluczyć faktu, że był to kongres, w którym uczestniczyła największa liczba badaczy, reprezentujących największą liczbę krajów świata ${ }^{83}$.

\section{STATISTICAL AND COMPARATIVE ANALYSIS OF THE $23^{\text {RD }}$ INTERNATIONAL CONGRESS OF BYZANTINE STUDIES (BELGRADE, 22-27 AUGUST 2016)}

(Summary)

The $23^{\text {rd }}$ International Congress of Byzantine Studies took place in the hospitable capital of Serbia from Monday (22 August) to Saturday (27 August 2016). According to official data in the congress took part 1,260 byzantine scholars from 48 countries of the world. The largest number of scientist represented Greece (212),

\footnotetext{
${ }^{81}$ Program of the $23^{\text {rd }}$ International Congress of Byzantine Studies, [s. X-XIII].

${ }^{82}$ Por. Kochanek, Udziat Polaków w 21 Międzynarodowych Kongresach Bizantynistów, s. 312, tab. II i nota 6.

${ }^{83}$ Por. tamże, s. 312, tab. II i nota 6 oraz s. 334. Większą liczbę uczestników miał mieć tylko XVIII Międzynarodowy Kongres Bizantynologiczny, który odbył się w Moskwie (8-15 VIII 1991). Szacuje się bowiem, że do stolicy Rosji przybyło 1300 badaczy. Jednak liczba ta sugeruje raczej wielkość przybliżoną niż dokładne określenie liczby uczestników kongresu moskiewskiego, stąd do tych danym należy podchodzić bardzo ostrożnie i uznać XXIII kongres za potencjalnie najliczniej obsadzony kongres bizantynologiczny w dotychczasowej historii tych międzynarodowych spotkań.
} 
Serbia (122), France (103), Russia (87), the United Kingdom (79) and Italy (78). Numerous scholars came to Belgrade also from Germany (72), the USA (64), Bulgaria (57), Turkey (40) and Austria (39). Poland was represented officially by 26 byzantine scholars. To this number must be added two Poles affiliated to foreign universities. Most Polish researchers, as many as 11, represented the University of Lodz - today the most important Polish center for research on the history and culture of Byzantium. During the congress 1148 scholars presented 1329 papers and communications. According the official data 1057 papers $(=79,533 \%)$ were in English, 165 in French (= 12,415\%), 30 in Greek (=2,257\%), 28 in German $(=2,106 \%), 28$ in Russian $(=2,106 \%)$ and $21(=1,580 \%)$ in Italian. Twenty-six Poles representing the Polish research centers presented a total of 29 communications (26 in English, 1 in French, 1 in German and 1 in Russian). Furthermore, one Pole affiliated to the Johannes Gutenberg University of Mainz, delivered his communication in French. According the official data, the congress was divided into several program blocks. The first block was the solemn opening session. Part of this session was the inaugural lecture of professor John F. Haldon from Princeton University. On the other hand, during the six plenary sessions were delivered 20 papers. The third block of the congress were the round table sessions. These sessions were a total 49 ( $=382$ communications). There have also been 116 sessions of free communications, during which 843 papers were read. Furthermore, during the six special sessions the participants delivered 64 presentations. Finally, a separate block were two poster sessions. In these sessions attended 19 authors. The sessions of the congress were held either at the Faculty of Philology (3 Studentski trg) or at the building of the Serbian Academy of Sciences and Arts (35 Knez Mihailova St.). It was agreed that the $24^{\text {rd }}$ International Congress of Byzantine Studies will be held in 2021 in Istanbul.

Keys words: International Congresses of Byzantine Studies, statistics, comparison, participation of Poles.

Słowa kluczowe: Międzynarodowe Kongresy Studiów Bizantynologicznych, statystyka, porównanie, udział Polaków.

\section{BIBLIOGRAFIA}

Caseau B., Rituels chrétiens et sensorialité, w: Proceedings of the $23^{\text {rd }}$ International Congress of Byzantine Studies. Plenary Papers, ed. S. Marjonović-Dušanić, Belgrade 2016, 159-173.

Ilski K. - Koкoszko M. - Kompa A., Komunikat 6/2016: Sekcja Bizantynologiczna KNoKA PAN. Komisja Bizantynologiczny PTH (Łódź, 5 września 2016) [Ten druk ulotny to dwie, nienumerowane strony].

Kochanek P., XXII Międzynarodowy Kongres Bizantynistów (Sofia, 22-27 VIII 2011), VoxP 31 (2011) t. 56, 942-951.

Kochanek P., Udział Polaków w 21 Międzynarodowych Kongresach Bizantynistów w latach 1924-2006, VoxP 32 (2012) t. 57, 309-335. 
KozŁowski M., Kazimierz Zakrzewski na tle dyskusji o upadku cesarstwa rzymskiego w polskiej historiografii okresu międzywojennego, w: Kazimierz Zakrzewski. Historia i polityka, red. M. Dąbrowska, Warszawa - Łódź 2015, 46-63.

List of participants of the 23rd International Congress of Byzantine Studies (Belgrade, 2227 August 2016), Belgrade 2016.

List of participants of the $23^{\text {rd }}$ International Congress of Byzantine Studies. Additions and corrections, Belgrade 2016 [Lista ta to jednostronicowy dodatek znajdujący się $\mathrm{w}$ teczce $\mathrm{z}$ materiałami kongresowymi, które otrzymywał każdy oficjalnie zapisany uczestnik].

Naumowicz J. - Salamon M., Profesor Oktawiusz Jurewicz (30 IV 1926 - 28 IV 2016), VoxP 66 (2016) t. 66, 715-719.

Proceedings of the $23^{\text {rd }}$ International Congress of Byzantine Studies. Plenary Papers, ed. S. Marjonović-Dušanić, Belgrade 2016.

Program of the 23 ${ }^{\text {rd }}$ International Congress of Byzantine Studies (Belgrad, 22-27 August 2016), Belgrade 2016.

Program of the $23^{\text {rd }}$ International Congress of Byzantine Studies. Additions and corrections, Belgrade 2016 [Errata ta to trzystronicowy dodatek dołączony do teczki z materiałami kongresowymi, którą otrzymywał każdy oficjalnie zarejestrowany uczestnik]. 
